URŠKa VALENČIČ ArH

FILOZOFSKA FAKULTETA UNIVERZE V LJUBLJANI

LJUBLJANA, SLOVENIJA

urska.valencicarh@ff.uni-lj.si

https://doi.org/10.17234/9789531755139.31

\title{
KDO JE V TRGOVINI S PORCELANOM? - ANALIZA ŽIVALSKIH SESTAVIN V FRAZEMU Z DIAHRONEGA VIDIKA
}

\begin{abstract}
Članek obravnava etimologijo frazema kot slon $v$ trgovini s porcelanom, ki je kot primerjalni frazem s sestavino slon poznan $\mathrm{v}$ germanskih, romanskih, slovanskih in drugih jezikih. Natančen izvor nastanka frazema ni znan. V prvem delu prispevka predstavljamo nekaj že obstoječih etimoloških razlag ter na podlagi primerjalne analize iz starejših in sodobnih literarnih ter drugih virov dodajamo nove možne teorije nastanka. V nadaljevanju se posvečamo rabi frazema v slovenskem jeziku tako na strukturni in pomenski ravni kot tudi s prevodnega vidika.
\end{abstract}

Ključne besede: etimologija, živalska sestavina, prevajanje, konotacija, leksikografija

\section{Uvod}

Diahroni vidik v frazeološki teoriji je pogosto predmet raziskav, s katerimi jezikoslovci ugotavljajo zakonitosti v razvoju neke stalne besedne zveze od začetka do danes. Pri raziskovanju etimologije frazema moramo upoštevati najrazličnejše možnosti nastanka in dejavnike, ki so vplivali na nastanek ustaljene oblike. Frazeološke enote nastanejo na različne načine: a) iz proste besedne zveze zaradi novih metonimičnih/ metaforičnih pomenskih prenosov, b) če posamezne sestavine izgubijo svoj prvotni pomen in tvorijo nov frazeološki pomen, c) če se izgubi prvotna motivacija kot posledica napačnega razumevanja $\mathrm{v}$ procesu ljudskega etimološkega prenosa in d) kot izposojenke iz tujega jezika. Pri raziskovanju etimologije primerjalnega frazema kot slon $v$ trgovini s porcelanom nas je presenetil podatek, da je ta frazem stalna primera s sestavino slon v kar 31 jezikih (Piirainen 2012: 478). Da bi prikazali njegovo razširjenost, povzemamo nekatere oblike: v nemščini wie ein Elefant im Porzellanladen, v švedščini som en elefant $i$ en glasbutik, v francoščini comme un éléphant dans un magasin de porcelaine, v španščini como un elefante en una cacharrería, v romunščini ca un elefant întrun magazin de porțelanuri, v ruščini как слон в посудной лавке, v hrvaščini kao slon u prodavaonici porculana/ u staklani/ trgovini porculana/ porcela$n a, v$ madžarščini elefánt a porcelánboltban, $\mathrm{v}$ estonščini nagu elevant portselanipoes. Primerjalni frazemi ali primerjalni jezikovni izrazi, kot jih tudi imenuje Kržišnik (2008: 39), so izraz ,odnosa do okolja in življenjskih okoliščin, v katerih se nahajajo rojeni govorci“, ali pa „lahko izražajo fizične ali psihične lastnosti človeka in temeljijo na povezovanju z živalmi, rastlinami, naravnimi pojavi.“. Že zaradi sestavine slon lahko domnevamo, da ta primerjalni frazem $\mathrm{v}$ mnogih jezikih ni nacionalnokulturno 
specifičen, zato smo se $\mathrm{v}$ nadaljnji raziskavi osredotočili na morebitni skupni vir in posledično na kalkiranje ter prevzemanje v drugih jezikih v smislu "frazeoloških kalkov“ (Toporišič 1973/74: 279).

\section{Struktura in pomen frazema kot slon $v$ trgovini s porcelanom}

V Slovarju slovenskih frazemov (Keber 2011: 868) je pod geslom slon naveden primerjalni frazem kot slòn v trgovini s porcelanom v pomenu 'zelo nerodno, nespretno', ki se „največ uporablja z glagoloma obnašati se, vesti se“ (ibid.). Primerjalne frazeme tvorimo po ustaljeni modelni predlogi. Po Fink-Arsovski (2002: 12) sta znana dva osnovna strukturna tipa: trodelni $\mathrm{A}+\mathrm{B}+\mathrm{C}$ in dvodelni $\mathrm{B}+\mathrm{C}$. Del A pomeni sestavino, ki se primerja (obnašati se), del B je primerjalni veznik (npr. ko, kot, kakor) in del C (slon $v$ trgovini s porcelanom) z eno sestavino ali več sestavinami, s katero se primerja del A. Struktura primerjave v prenesenem pomenu služi kot slikovita, retorično olepševalna formula za pomensko stopnjevanje oz. poudarjanje. Sestavina slon v primerjalnem frazemu [obnašati/vesti se] kot slon v trgovini s porcelanom namiguje na to, da na nastanek primerjalnega frazema ni vplival odnos do okolja, $\mathrm{v}$ katerem so živeli slovenski govorci, saj to okolje ni domovina te živali. V slovenskem oz. slovanskem prostoru so slona v zgodovini poznali le po pripovedovanju, ker je njihovo naravno okolje v vzhodni Indiji in južni Afriki. Beseda slon je splošnoslovanska in zapisana v starocerkvenoslovanskih besedilih (Keber 1998: 236). Slonu v prvih zapisih v slovenskem jeziku pripisujejo predvsem pozitivne lastnosti:

„Slon je kaj čudna žival; po truplu je človeku sicer malo podoben, tim bolj pa po dušnih zmožnostih. Slon ima lastnosti, kakoršne se pri človeku zeló čislajo, p. sodružno vernost, ljubezen do mladičev in staršev, zvestobo, sramožljivost, pravičnost, usmiljenje, prizanesljivost, zatajevanje samega sebe tudi kedar je razdražen in jezen, in žertvuje tudi življenje za vse, kar mu je milo in drago.“ (Živkov 1866: 58).

Razlaga izvora temelji na izglagolskem samostalniku sloneti in ljudskoetimološko se je beseda slon v slovanskih jezikih uveljavila na prepričanju, da je slon žival, ki spi naslonjena na drevo (Snoj 1997: 582). Tudi Trošt (1910: 177) je zapisal: „Ime ima slon baje odtod, ker ne spi ležeč, marveč se nasloni na drevesno deblo." Metaforično dodano razlago s stilistično oznako 'šaljivo za človeka, ki se vsepovsod in vedno nekam naslanja' najdemo v Murkovem slovarju iz leta $1833 .{ }^{1} \mathrm{~V}$ Slovarju slovenskega knjižnega jezika je dodatna pomenska vrednost leksema slon ujeta v pomenu 'velik, neroden človek'. Frazem [obnašati/vesti se] kot slon v trgovini s porcelanom v pomenu 's svojim nerodnim in grobim obnašanjem povzročiti škodo' razlaga Krüger-Lorenzen (1995:

Pod geslom slon je zapisana naslednja razlaga: ,scherzweise auch ein Mensch, der überall und immer herumlehnt.“ (Murko 1833: 264). 
397) kot večno podcenjevanje značaja, ki ga ljudski jezik pripisuje sicer zelo pametni in previdni živali. Slon je največji predstavnik kopenskih sesalcev, ki mu zaradi svoje teže ( $5-7$ ton) in velikosti ( $3-4$ metrov) pripisujemo nerodnost, saj prav nasprotje med krhkimi izdelki iz porcelana in orjaškim živalskim velikanom botruje podobi o uničenju in razbitinah, če si predstavljamo, da se slon v resnici premika po trgovini s porcelanom. Nerodno obnašanje je $\mathrm{v}$ metaforiki povezano tudi $\mathrm{z}$ drugimi velikimi živalmi kot so govedo, bik, krava, konj in druge (prim. Keber 1998: 237).

Sestavina porcelan je prevzeta prek nemškega leksema Porzellan iz italijanskega porcellana, ki je poznan od 13. stoletja dalje, ko je Marco Polo prinesel porcelan iz Kitajske (Snoj 1997: 472). Natančna etimologija frazema ni znana, vendar obstajajo teorije, ki so si enotne v tem, da je izposojenka iz angleškega frazema like a bull in a china shop. $\mathrm{Z}$ izvorom frazema slon $v$ trgovini s porcelanom $\mathrm{v}$ nemščini se je izčrpno ukvarjala jezikoslovka Olga V. Trokhimenko, ki navaja (1999: 352), da so konec 15. stoletja arabski in portugalski trgovci $v$ Italijo prinesli fine kitajske in japonske glinene izdelke z Daljnega Vzhoda, ki so jih v Italiji poimenovali porcellana. Poimenovanje so prevzeli v francoščini z izrazom porcelaine, $\mathrm{v}$ nemščini z izrazom Porzellan in v Angliji $\mathrm{z}$ izrazom porcelain. $\mathrm{V}$ angleščini so to vrsto posode zaradi dežele porekla imenovali tudi china ter v starejši obliki tudi china-ware. ${ }^{2}$

\title{
3 Teorije o nastanku
}

Po navedbah frazeologinje Trokhimenko (1999: 352) obstajajo v frazeološki literaturi tri različne teorije nastanka frazema. Po prvi teoriji naj bi frazem nastal iz Ezopove basni The peeping ass, ki jo v svoji zbirki Aesopica pod številko 459 navaja jezikoslovec Ben Edwin Perry. Zapis v angleščini citiramo iz Trokhimenko (1999: 352):

\begin{abstract}
„A potter kept many birds in his shop. An ass whose driver was not keeping very good track of him came by, put his head in the window, and brayed at the birds. They flew up and smashed all the vessels in the shop. The owner of the shop haled the driver into court. When the passers-by asked the driver what he was being charged with, he said: A peeping ass." ${ }^{\text {. }}$.
\end{abstract}

Po drugi teoriji (Trokhimenko 1999: 354) etimologijo frazema povezujejo z lastnim imenom in angleško nacionalno figuro Johna Bulla, ki je imel s svojo družbo East Indian Company monopol nad trgovino s Kitajsko. Kot fiktivna ponazoritev angleškega značaja in britanskega imperializma se je John Bull prvič pojavil v satiri Johna Arbuthnota

2 Zapis v slovarju A Dictionary of the English Language avtorja Samuela Johnsona iz leta 1768: „CHI'NA. [from China] China ware; porcelain [...]“.

3 Prevod v slovenščini: „Lončar je imel v svoji prodajalni veliko ptičev. Nekega dne je osel, ki ga voznik ni dovolj brzdal, potisnil glavo v prodajalno in tako prestrašil ptiče, da so naredili pravo opustošenje. Lončar je zahteval povračilo, in ko so mimoidoči vprašali voznika, česa je obtožen, je odvrnil: Radovednega osla.". 
(1667-1735) Law is a bottomless-Pit. Or, The History of John Bull leta 1712, v kateri je Arbuthnot napadel zunanjo politiko in finančne kroge, ki so iz angleške intervencije $v$ Evropi kovali dobiček. Arbuthnotov John Bull je bil pošten mali trgovec. Po značaju je bil prijateljski in tovariški, a tudi vzkipljiv in nestanovitnega značaja. Posel mu je sprva cvetel, toda ker se je po nasvetu svojih odvetnikov podal v tožbo, ki naj bi se čez leto ali dve končala v njegov prid, je zašel v finančne težave. Arhetipsko podobo Angleža kot otopelega, razdražljivega in nemalokrat rahlo v rožicah so pogosto primerjali z bikom, volom ali kravo. Arbuthnot je vse te predstave združil v Johnu Bullu. Charles Funk (1948: 147) domneva, da je lastno ime John Bull kot sestavina v frazemu like a bull in a china shop podlaga za politično karikaturo, $\mathrm{v}$ kateri naj bi John Bull v podobi osla predstavljal neuspešne in nespretne posle med Anglijo in Kitajsko. Med slikarji omenja škotskega političnega satirika Georgea Cruishanka. Čeprav Funk (ibid.) o obstoju karikature in o njenem možnem naslovu John Bull in a China Shop, ki naj bi sčasoma prešel v eliptično rabo Bull ${ }^{4}$ in a China Shop ni povsem prepričan, Trokhimenko (1999: 354) pa v obstoj te karikature celo dvomi, smo pri našem raziskovanju v katalogu Karikatur und Zeichenkunst muzeja Wilhelm Busch Deutsches Museum für Karikatur iz Hannovra, ki ga je leta 2012 izdala urednica Vetter-Liebenow ob 75. obletnici muzeja, naleteli na ilustracijo z naslovom $A$ Bull in a China Shop. Po navedbah v katalogu (2012: 250) je ilustracija, ki upodablja pesem The Bull in the China Shop, delo dveh škotskih slikarjev in političnih satirikov, očeta Isaaca Cruikshanka (1756-1811) in sina Georgea Cruikshanka (1792-1878). Ilustracija naj bi nastala leta 1808 ob uprizoritvi predstave Harlequin Highflyer or Off she Goes v gledališču Aquatic Theater, Sadler Wells.

V tretji teoriji, ki jo navaja Trokhimenko (1999: 355), naj bi nastanku frazema like a bull in a china shop botroval resnični dogodek iz konca 18. stoletja, ki je kot novica opisan v časniku London Packet dne 17. marca 1773: „This morning an over drove bullock rushed into the china-shop of Miss Powell, opposite St. Andrew's church, Holborn, where he frightened the lady into a hysterical fit, and broke a quantity of glass and china." Podobno novico o resničnem dogodku smo zasledili tudi skoraj sto let kasneje v londonskem časopisu The Spectator (1861: 17-18), ki pa verjetno le potrjuje dejstvo, da so biki v Angliji pogosto podivjali in povzročali škodo, ker so frazem lika a bull in a china shop v literarnih virih uporabljali že pred letom 1861:

„This phrase generally considered as so strikingly emblematical of clumsiness, on Wednesday last turned out to be a literal fact, whilst its reputed emblem was singularly enough libellous. A fine horned bullock being driven into Braintree market was majestically proceeding down Bank-street, talking in his progress a calm survey of the various goos in the shop window, when, as if pre-arranged, and

Sčasoma naj bi se pri leksemu Bull (slov. bik) uveljavila raba male začetnice bull.

5 Pod številko 55 na strani 250 so navedeni naslednji podatki o karikaturi: , Isaac (1756-1811) und George (1792-1878) Cruikshank, The Bull in the China Shop, 1808, Der Stier im Porzellan-Laden, Tusche / Feder, Aquarell, laviert; 18,5 × $22 \mathrm{~cm}$ “. 
with an air of importance, he walked into the china and glass warehouse of. Mr. J.D.Smith.“.

$\mathrm{V}$ nadaljnji raziskavi smo naleteli na povezavo $\mathrm{z}$ arabščino in jo imenujemo četrta teorija. Švicar Johann Ludwig Burckhardt (1784-1817) $)^{6}$ je zbrane pregovore v arabščini uredil in prevedel v angleščino in v nemščino. Angleško zbirko je objavil leta 1830 pod naslovom Arabic proverbs, or the manners and customs of the modern Egyptians, nemško pa leta 1834 pod naslovom Arabische Sprüchwörter oder die Sitten und Gebräuche der neueren Aegpytier. Zanimiv je pregovor št. 209, ki je iz arabščine preveden v nemščino kot ein Stein in dem Laden eines Glashändlers (slov.: kamen v steklarjevi prodajalni) v pomenu, 'da nekaj sploh ni na svojem mestu'.7 Čeprav pomensko ne gre za ustreznico uslovarjenega pomena frazeološke primerjave [obnašati/vesti se] kot slon v trgovini s porcelanom je zanimiv namig na povezavo med arabskim frazemom in Ezopovo basnijo, na katero smo naleteli v londonski reviji The Quaterly Review iz leta 1868 na strani 245. Namiguje namreč na možno različico med zgoraj omenjenim grškim pregovorom in arabskim pregovorom: „,...) 'A storm in the shop of a glass-dealer' looks like a version of the Greek proverb we noted above, about the ass peeping into the crockery-shop.“.

\section{Frazem like a bull in a china shop v angleškem leposlovju in v nemških prevodih}

Kot prvo omembo frazema like a bull in a china shop v angleškem leposlovju navajajo delo Jacob Faithful pisatelja Fredericka Marryatsa (1792-1848) iz leta 1834 (Trokhimenko 1999: 356):

„As soon as Mr. Turnbull was dressed, we went down into the drawing-room, which was crowded with tables loaded with every variety of ornamental articles. Now this is what my wife calls fashionable. One might as well be steering through an ice-floe as try to come to an anchor here without running foul of something. It's hard-a-port or hard-a-starboard every minute; and if your coat-tail jibes, away goes something, and whatever it is that smashes, Mrs. T. always swears it was the most valuable thing in the room. I'm like a bull in a china-shop.“.

S primero like a bull in a china shop mladi Jacob opiše ne le svojo nerodnost, ampak se tudi posmehuje snobizmu, nevoščljivosti in nečimrnosti prijateljeve žene, ki ne dovoli nikomur, da bi se dotikal njenih lepih stvari.

$6 \quad$ Imenoval se je tudi Jean Louis Burckhardt, znan je bil tudi pod imenom Johann Ludwig in John Lewis. Njegov psevdonim je Sheikh Ibrahim Ibn Abdallah.

$7 \quad \mathrm{~V}$ angleški izdaji slovarja je isti frazem preveden kot $A$ storm in the shop of a glass-dealer $\mathrm{v}$ pomenu 'signifying that a thing is quite out of place'. 
$\mathrm{V}$ različnih prevodih tega romana v nemščino v 19. stoletju in pod naslovom Die Abenteuer des Jacob Ehrlich najdemo v nemščini dve različni ustreznici sestavine bull iz frazema like a bull in a china shop, to sta Stier (slov. bik) in Ochse (slov. vol):

1835: „Ich bin hier grade so, wie ein Stier im Porzellan-Laden.“

1843: "Ich gleiche einem Ochsen in einem Porzellanladen.“

1860: "Ich gleiche einem Ochsen in einem Porzellanladen.“

Angleški pisatelj William Makepeace Thackeray (1811-1863) je uporabil frazem v delu Vanity Fair, v katerem opisuje angleško plemiško in meščansko življenje v času Napoleona. Delo, ki je sprva izhajalo v mesečnih nadaljevanjih med januarjem 1847 in julijem 1848 pod naslovom Vanity Fair: Pen and Pencil Sketches of English Society, je v obliki romana v treh delih izšlo v Londonu leta 1848.V drugem delu iz leta 1848 je avtor v 32. poglavju pri opisu nerodnega jezdeca uporabil frazem such a bull in a china-shop:

„The horses, which had not been exercised for some days, were lively, and sprang about the street. Jos, a clumsy and timid horseman, did not look to advantage in the saddle. 'Look at him, Amelia dear, driving into the parlour window. Such a bull in a china-shop I never saw.'“.

V nemškem prevodu Der Markt des Lebens. Ein Roman ohne einen Helden iz leta 1849 izpod peresa prevajalca Augusta Diezmanna je frazem such a bull in a chinashop v ciljnem jeziku izpuščen. Sporočevalni namen (Jakop 2005: 46) primerjalnega frazema je prevajalec nadomestil z izrazom posmehovanja Wie lächerlich! (slov. Kako smešno!):

„Die Pferde, welche einige Tage gestanden hatten, waren muthig und jagten die Straßen hinab. Joseph, ein ängstlicher und unbehilflicher Reiter sah im Sattel nicht eben anziehend aus. »Sehen Sie ihm nur nach, Amalie! Wie lächerlich!«“"

Angleško izvirno besedilo Vanity Fair je v prevodu Christopha Friedricha Grieba izšlo pod naslovom Der Jahrmarkt des Lebens. V 32. poglavju drugega dela iz leta 1851 je izhodiščni primerjalni frazem such a bull in a china-shop v pomenu 'biti neroden' preveden s sestavino Ochse (slov.: vol):

„Die Pferde, die mehrere Tage hindurch nicht geritten worden waren, zeigten sich ungemein lebhaft, und sprangen von einer Seite der Straße zur andern. Jos, ein schwerfälliger und furchtsamer Reiter, nahm sich im Sattel nicht sonderlich gut aus. 'Sehen Sie doch hin, theure Amalie: er will ja dort zum Fenster hineinreiten. Noch nie im Leben sah ich einen solchen Ochsen in einem Porzellan-Laden.'“. 
Ker smo prevod nemške izdaje iz leta 1851 preverili v faksimilirani izdaji, nas je tem bolj presenetil prevod tega odstavka na spletni strani projekta gutenberg.spiegel. $d e^{8}$. Kot vir je navedena izdaja pod naslovom Jahrmarkt der Eitelkeit iz leta $1851 \mathrm{v}$ prevodu Christopha Friedricha Grieba. Na istem mestu v omenjenem odstavku smo zasledili zapis frazeološke primerjave s sestavino Elefant (slov.: slon):

„Die Pferde, die ein paar Tage lang keine Bewegung gehabt hatten, waren lebhaft und machten frohe Sprünge auf der Straße. Joseph war ein ungeschickter, ängstlicher Reiter und wirkte im Sattel sehr unvorteilhaft. 'Sehen Sie nur, liebe Amelia, er reitet geradezu in das Fenster dort hinein. So einen Elefanten im Porzellanladen habe ich noch nie gesehen.'“.

Povsem identičen prevod je objavljen na spletnih straneh digitalne knjižnice Zeno9. Med podatki lahko razberemo, da je za podlago spletni izdaji prav tako služila izdaja Jahrmarkt der Eitelkeit iz leta 1964 v prevodu Christopha Friedricha Grieba:

„Die Pferde, die ein paar Tage lang keine Bewegung gehabt hatten, waren lebhaft und machten frohe Sprünge auf der Straße. Joseph war ein ungeschickter, ängstlicher Reiter und wirkte im Sattel sehr unvorteilhaft. 'Sehen Sie nur, liebe Amelia, er reitet geradezu in das Fenster dort hinein. So einen Elefanten im Porzellanladen habe ich noch nie gesehen."“.

$\mathrm{V}$ tabeli 1 so predstavljeni vsi omenjeni prevodi z različnimi sestavinami, poleg Stier (slov.: bik) tudi Ochse (slov. vol) in Elefant (slov. slon).

\begin{tabular}{|l|l|l|l|l|}
\hline \multirow{2}{*}{$\begin{array}{l}\text { Frederick } \\
\text { Marryats: }\end{array}$} & \multicolumn{1}{|c|}{1834} & \multicolumn{1}{c|}{1835} & \multicolumn{1}{c|}{1843} & \multicolumn{1}{c|}{1860} \\
\cline { 2 - 5 } Jacob Faithful & $\begin{array}{l}\text { I'm like a } \\
\text { bull in a } \\
\text { china-shop. }\end{array}$ & $\begin{array}{l}\text { Ich bin hier grade } \\
\text { so, wie ein Stier im } \\
\text { Porzellan-Laden. }\end{array}$ & $\begin{array}{l}\text { Ich gleiche } \\
\text { einem Ochsen } \\
\text { in einem } \\
\text { Porzellanladen. }\end{array}$ & $\begin{array}{l}\text { Ich gleiche } \\
\text { einem Ochsen } \\
\text { in einem } \\
\text { Porzellanladen. }\end{array}$ \\
\hline
\end{tabular}

$8 \quad$ Projekt Gutenberg je najstarejša in zbirka elektronskih knjig oziroma besedil. Njegovi začetki segajo v leto 1971, ko je Američan Michael Hart začel v elektronsko obliko prepisovati klasična literarna dela. (Ločniškar-Fidler, 2003: 160). Zbirka, ki živi še danes, ponuja brezplačno dostopna dela in je vsak dan obsežnejša, tako da po najnoveših podatkih obsega preko 5500 klasičnih in strokovnih del 1100 avtorjev.

9 Digitalna knjižnica zeno.org je bila ustanovljena septembra 2007 in obsega besedila iz zbirke Digitale Bibliothek, slikovno gradivo projekta Yorck Projec in nemške spletne strani wikipedia. 


\begin{tabular}{|l|l|l|l|l|}
\hline & \multicolumn{1}{|c|}{1848} & 1849 & 1851 & \multicolumn{1}{c|}{$\begin{array}{c}1851 \\
\text { Gutenberg/zeno }\end{array}$} \\
\cline { 2 - 5 } $\begin{array}{l}\text { William } \\
\text { Makepeace } \\
\text { Thackeray: }\end{array}$ & $\begin{array}{l}\text { Such a bull } \\
\text { in a china- } \\
\text { shop I never } \\
\text { Sawity Fair }\end{array}$ & Wie lächerlich! & $\begin{array}{l}\text { Noch nie im } \\
\text { Leben sah ich } \\
\text { einen solchen } \\
\text { Ochsen } \\
\text { in einem } \\
\text { Porzellan- } \\
\text { Laden. }\end{array}$ & $\begin{array}{l}\text { So einen } \\
\text { Elefanten im } \\
\text { Porzellanladen } \\
\text { habe ich noch } \\
\text { nie gesehen. }\end{array}$ \\
\hline
\end{tabular}

Tabela 1. Pregled živalskih sestavin v nemških prevodih

Tretje literarno delo v angleščini, ki ga predstavljamo v prispevku, je orientalska romanca z naslovom Lalla Rookh, ki jo je pisatelj Thomas Moore (1779-1852) napisal leta 1817 in nosi ime po junakinji in hčerki mogulskega osvajalca. V delu se prepletata poezija in zgodbe $\mathrm{v}$ prozi, zanimiv pa je opis dogodka, v katerem se slon nerodno obnaša in razbije porcelan, torej gre za dobesedno in ne za frazeološko branje (prim. Kržišnik 2006: 260):

„In the next place, the elephant laden with his fine antique porcelain, had, in an unusual fit of liveliness, shattered the whole set to pieces.“.

Tudi v nemškem prevodu z naslovom Lalla Rookh, ki je izšel leta 1826, nastopa nerodni slon:

„Zum Zweiten hatte der Elephant, der ihm sein feines altes Porzellan trug, in einem ungewöhnlichen Anfalle von Lebhaftigkeit, die ganze Tracht zertrümmert.“.

Podoba nerodnega slona bi lahko bil motiv za nastanek frazema s sestavino slon, ker se nekako vključuje v jezikovno sliko orientalske podobe sveta. Poleg tega je to delo nastalo leta 1817, torej sedemnajst let pred prvo omembo like a bull in a china shop $\mathrm{v}$ angleškem leposlovju leta 1834.

\section{Frazem [sich benehmen] wie ein Elefant im Porzellanladen v slovarjih}

Izhajajoč iz predpostavke, da je angleška frazeološka primera like a bull in a china shop osnova za izpeljanko stalne besedne zveze slon v trgovini s porcelanom, ki je verjetno izposojenka wie ein Elefant im Porzellanladen iz nemščine, je potrebno omeniti tudi nekaj besed o nemškem frazemu. O etimologiji tega frazema v nemščini je zapisano zelo malo. Tudi v standardem delu Lexikon der sprichwörtlichen Redensarten (1991) paremiologa Röhricha, ki se najbolj podrobno ukvarja z etimologijo frazemov in pregovorov v nemškem prostoru, ni podatka o tem frazemu. Slovarski opisi angleškega like a bull in a china shop pa so vendarle bili zapisani že sredi 19. stoletja. To dokazuje zapis 
v Lucasovem (1854: 253) dvojezičnem angleško-nemškem slovarju, kjer smo našli naslednji prevod v nemščino: ,to be as awkward as a bull in a china shop; so ungeschickt sein, wie der Stier im Porzellanladen (von einer sehr ungeschickten, unmanierlichen, bäuerlichen Person gesagt). ${ }^{10}$ Čeprav je nemško ustreznico wie ein Elefant im Porzellanladen angleškega frazema like a bull in a china shop mogoče najti v dvojezičnih angleško-nemških slovarjih iz 2. polovice 20. stoletja ${ }^{11}$, pa je zanimivo, da sta v Dornseiffovem onomaziološkem slovarju iz leta $1970^{12} \mathrm{v}$ besedni zvezi s sestavino Porzellanladen (slov.: trgovina s porcelanom) navedeni sestavina Esel (slov: osel) v besedni zvezi wie der Esel im Porzellanladen ${ }^{13}$ (ibid.: 275) pod pomenskim opisom Unzweckmäßigkeit (slov. nesmotrnost) in sestavina Ochse (slov.: vol) v besedni zvezi Ochse im Porzellanladen $^{14}$ (ibid.: 316) pod geslom geschmacklos (slov. neokusno). V frazeološkem slovarju DUDEN 11, ki velja za najpreglednejšo in najobsežnejšo zbirko frazemov v nemško govorečem prostoru, smo v 1. in 2. izdaji opazili strukturno in pomensko razliko, neke vrste metaforični razvoj v ustaljenosti stalne besedne zveze. V prvi izdaji (1992 : 98) je frazem sich wie ein Elefant im Porzellanladen benehmen (slov.: obnašati se kot slon v trgovini s porcelanom) pojasnjen v pomenu 'durch Ungeschicklichkeit Unheil anrichten' (slov.: 'zaradi nespretnosti povzročiti nesrečo/zlo'). V 3., predelani izdaji (2008: 190) pa je pod geslom Elefant (slov. slon) zapisan frazem wie ein Elefant im Porzellanladen (slov.: kot slon v trgovini s porcelanom) v pomenu 'durch äußerst ungeschicktes, grobes Verhalten Schaden anrichtend' (slov.: 'napraviti škodo z zelo nespretnim, grobim vedenjem/obnašanjem'). V novejši obliki je izpuščen glagol sich benehmen (slov. obnašati se), pri pomenski razlagi pa je dodana 'grobost' in okrepljena 'nespretnost'. V spodnji tabeli je prikazana raznolikost živalskih sestavin v različnih slovarskih zapisih v nemščini.

\begin{tabular}{|c|c|c|c|c|c|c|}
\hline 1854 & 1870 & 1981 & 1983 & 1991 & 1992 & 2008 \\
\hline $\begin{array}{l}\text { Englisch- } \\
\text { deutsches } \\
\text { und deutsch- } \\
\text { englisches } \\
\text { Wörterbuch } \\
\text { (Lucas) }\end{array}$ & $\begin{array}{l}\text { Der } \\
\text { deutsche } \\
\text { Wortschatz } \\
\text { nach Sach- } \\
\text {-gruppen } \\
\text { (Dornseiff) }\end{array}$ & $\begin{array}{l}\text { Handwörter- } \\
\text {-buch Engli- } \\
\text { sch-Deutsch } \\
\text { (Messinger/ } \\
\text { Rüdenberg) }\end{array}$ & $\begin{array}{l}\text { An English- } \\
\text { German } \\
\text { Dictionary of } \\
\text { Idioms } \\
\text { (Engeroff/ } \\
\text { Lovelace- } \\
\text {-Käufer) }\end{array}$ & $\begin{array}{l}\text { Lexikon der } \\
\text { sprichwört- } \\
\text { lichen } \\
\text { Redensarten } \\
\text { (Röhrich) }\end{array}$ & $\begin{array}{c}\text { DUDEN } \\
11\end{array}$ & $\begin{array}{c}\text { DU- } \\
\text { DEN } \\
11\end{array}$ \\
\hline
\end{tabular}

$\overline{10}$ Prevod nemškega besedila: „,biti tako nespreten/neroden kot bik v trgovini s porcelanom (rečemo o osebi, ki je nerodna, brez manir, kmečka).

11 Npr. v slovarju Handwörterbuch Englisch-Deutsch založbe Langenscheidts (1986: 90), v frazeološkem slovarju An English-German Dictionary of Idioms (1983: 39).

12 Dornseiffov slovar Der deutsche Wortschatz nach Sachgruppen (1. izdaja 1933-1940) velja v nemškem prostoru za najpomembnejši slovar po onomaziološko sistematični razvrstitvi, torej po ključnih pojmih ter nadpomenkah, kar omogoča razumevanje sopomenskosti.

13 V slov.: kot osel $v$ trgovini s porcelanom.

$14 \quad$ V slov.: vol $v$ trgovini s porcelanom. 


\begin{tabular}{|c|c|c|c|c|c|c|}
\hline $\begin{array}{l}\text { wie der } \\
\text { Stier im }\end{array}$ & $\begin{array}{c}\text { wie der Esel } \\
\text { im Porze- } \\
\text { llanladen }\end{array}$ & wie ein & wie ein & & $\begin{array}{l}\text { sich wie } \\
\text { ein } \\
\text { Elefant }\end{array}$ & wie ein \\
\hline $\begin{array}{l}\text { Porzellan- } \\
\text { laden }\end{array}$ & $\begin{array}{l}\text { Ochse im } \\
\text { Porzellan- } \\
\quad \text { laden }\end{array}$ & $\begin{array}{l}\text { Porzellan- } \\
\text { laden }\end{array}$ & $\begin{array}{l}\text { im Porzellan- } \\
\text { laden }\end{array}$ & - & $\begin{array}{c}\text { im } \\
\text { Porzellan- } \\
\text { laden } \\
\text { benehmen }\end{array}$ & $\begin{array}{l}\text { im Por- } \\
\text { zellan- } \\
\text { laden }\end{array}$ \\
\hline
\end{tabular}

Tabela 2. Pregled živalskih sestavin v nemščini v slovarjih

\section{Frazem like a bull in a china shop v slovenskih prevodih}

Primerjava med rabo frazema like a bull in a china shop v angleških izvirnih besedilih in slovenskih prevodnih besedilih je pokazala, da se stalnost sestavine slon v slovenskem

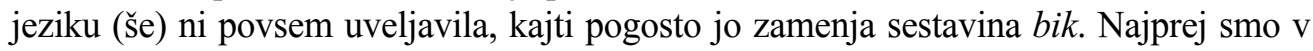
analizo vključili prevode literarnih del in navajamo tri različne prevode v slovenščino.

1. „Look at him, Amelia dear, driving into the parlour window. Such a bull in a china-shop I never saw.“ (William M. Thackeray: Vanity Fair, 1848)

„Poglej ga, Amelija, draga moja, saj bo zajahal skozi okno v salon. Jaz nisem še nikoli videla takega bika v trgovini s porcelanom." (William M. Thackeray: Semenj ničevosti: roman brez junaka 1946)

2. „In the shell pink interior of Sabrina Fair the Sergeant and his satellite looked as out of place as the traditional bull in a china shop." (Agatha Christie: Hickory, Dickory, Death, 1955)

„V nežno rožnati notranjosti Sabrine Fair sta bila stražmojster in njegov satelit videti prav tako doma kot pregovorni slon v trgovini s porcelanom.“" (Agatha Christie: Vija, vaja, ven, 1997)

3. „'Now I must go on. Dear me, while I have been talking to you, at least nine new species have escaped me.' And on went the giant, behind before, like a bull in a china-shop, till he ran into the steeple of the great idol temple (...)“(Charles Kingsley: The Water-Babies, 1916)

,'Zdaj pa moram naprej. Medtem ko sem klepetal s tabo, sem spregledal najmanj devet zanimivih primerkov.' Stekel je dalje, ljudje pa so bežali pred njim in verjetno beže še danes.“ (Charles Kingsley: Povodni otroci, 1995)

V prevodih umetnostnih besedil je v slovenščini v prvem prevodu iz leta 1946 uporabljena sestavina bik, v drugem prevodu iz leta 1997 je ustreznica slon in kaže na pravilno dekodiranje $\mathrm{v}$ prevodnem postopku substitucije ter na prevajalkino frazeološko kompetenco. V tretjem prevodu izvirnika iz leta 1916 pa je frazem v prevodu iz leta 1995 preprosto izpuščen, morda tudi zato, ker ga prevajalec ni prepoznal. 
$\mathrm{V}$ nadaljevanju smo primerjali prevode in izvirnike $\mathrm{v}$ neumetnostnih besedilih, $\mathrm{v}$ katerih se pojavlja angleški frazem like a bull in a china shop, in navajamo naslednja zgleda, v katerih je uporabljena sestavina bik.

4. „Director Hill adds, 'In England, Garfield's not only a fish out water, he's a bull in a china shop." " (http://www.ign.com/articles/2006/06/12/preview-garfield-a-tail-of-two-kitties)

„Režiser Hill dodaja: 'V Angliji Garfield ni le riba na suhem, je bik v trgovini s porcelanom.'“ (http://www.kolosej.si/filmi/film/garfield_2_s_podnapisi)

5. „Biden added, 'Some have said that sending you to New York would be like sending the bull into a China shop." (The New York Times, 2005)

„Njen kolega Joseph Biden pa je z vnaprej pripravljeno izjavo poskrbel, da se je znašel v vseh televizijskih prispevkih: 'Če vas pošljemo v New York, se bojim, da bo videti tako, kot bi poslali bika v trgovino s porcelanom,' je rekel.“ (Dnevnik, 2005)

Raba sestavine bik tudi v novejših prevodih neumetnostnih besedil iz angleščine kaže na to, da se sestavina slon $\mathrm{v}$ primerjalnem frazemu kot slon $v$ trgovini s porcelanom v slovenščini (še) ni povsem ustalila ali pa, da je prevajalec v svoji frazeološki kompetenci ni usvojil.

\section{Frazem kot slon v trgovini s porcelanom v slovenskih umetnostnih besedilih}

V dvojezičnih slovarjih, predvsem v jezikovnem paru slovenščina-nemščina, kjer so zapisane in ohranjene oblike neke ustaljene frazeološke enote, smo našli frazem biti kot slon v trgovini s porcelanom le v slovarju avtorice Elizabete M. Jenko (1994: 86). Nato se frazem pojavi šele v Kebrovem frazeološkem slovarju leta 2011. ${ }^{15}$ Pogled v spletna besedilna korpusa Nova beseda in Gigafida pa vendarle potrjuje njegovo rabo tako $\mathrm{v}$ neumetnostnih, publicističnih besedilih kot tudi $\mathrm{v}$ umetnostnih besedilih pred letom 2011. Pojavitev frazema v slovenskih umetnostnih besedilih v 20. stoletju kaže na variantnost pri sestavini trgovina oz. prodajalna.

1. „Oficir brez fantazije je kot pesnik brez navdiha, oficir fantast pa je v tej situaciji kot slon v trgovini s porcelanom. Enih in drugih imamo dovolj, pa delaj z njimi!“ (Tone Svetina: Ukana, 1965)

2. „Ples z dekletom, z Vido, in potem fant, ki se ni otresel svojih kmetiških navad, očitno eden študentov, ki vsipajo modre izreke in stihe klasikov, kot bi jih stresali

$\overline{15} \quad$ Frazem omenja Keber tudi v delu Živali v prispo dobah (1998). 
iz rokava, sicer pa se vedejo kot slon $\mathbf{v}$ prodajalni porcelana - smešni patroni so (...).“ (Mimi Malenšek: Pojoči labodi, 1970)

3. „Vse je razbila, kar ji je prišlo v roke. 'Oh Adi,' sem ji večkrat rekla, 'ti si kot slon $\mathbf{v}$ trgovini s porcelanom. Za tabo zmeraj ostanejo črepinje.'“ (Katarina Marinčič: Rožni vrt, 1992)

4. „Krpan je slon v prodajalni porcelana: kamorkoli se obrne, zdrobi skrbno urejeni protokol in ceremonial junaka v visoki epiki." (Aleksander Zorn: Nacionalni junaki, narcisi in stvaritelji, 1999)

5. „Ta moja nesrečna vljudnost, kaj hočeš, slon v trgovini s porcelanom, ki spretno prestopi prvo skodelico in trešči naravnost v servis (...).“ (Andrej Capuder: Reka pozabe, 2007)

\section{Zaključek}

Analiza je pokazala, da natančnega nastanka frazema [obnašati/vesti se] kot slon $v$ trgovini s porcelanom ne moremo opredeliti. Četudi obstoječe teorije namigujejo na izposojenko iz angleškega like a bull in a china shop, bi za resničen in trden dokaz o nastanku frazema morali nujno raziskati starejše besedilne vire tudi iz jezikov, v katerih je sestavina slon nacionalnokulturno specifična. To je potrdil odlomek iz orientalske romance Lalla Rookh. V nemških prevodih izhodiščnega frazema like a bull in a china shop iz angleškega leposlovja 18. stoletja se je pokazala variantnost pri izbiri sestavine bull, saj so uporabljali tudi sestavine Ochse in Stier. Ob tem se poraja misel, da je morda prav nemški prevod romana Jahrmarkt der Eitelkeit iz leta 1851 s sestavino Elefant (slov: slon) ustalil stalno besedno zvezo v nemščini. Z natančnejšo raziskavo vseh nemških preovodov in izdaj izvirnika Vanity Fair bi lahko odgovorili na vprašanje, zakaj, kdaj in kako je sestavina Ochse (slov. vol) prešla v Elefant (slov. slon) v nemškem prevodu. V slovenščini so sestavljalci slovenskih slovarjev v preteklosti frazem prezrli, čeprav bi ga morali vključiti v slovarsko gradivo že zaradi pogostnosti rabe. Podrobnejša analiza slovenskih besedil bi morda lahko odgovorila tudi na vprašanje, ali je bil frazem [obnašati/vesti se] kot slon v trgovini s porcelanom sprva rabljen v knjižnih zvrsteh in ali je kot izposojenka iz nemškega jezika preko prevodnega besedila prešel v slovenski jezik. 


\section{LITERATURA}

Capuder, Andrej. 2007. Reka pozabe. Ljubljana: Slovenska matica.

Christie, Agatha. 1955. Hickory, Dickory, Death. New York: Pocket Books.

Christie, Agatha. 1997. Vija, vaja, ven. Ljubljana: Mladinska knjiga.

Fink-Arsovski, Željka. 2002. Poredbena frazeologija: pogled izvana i iznutra. Zagreb: FF press.

Funk, E. Charles. 2002. A Hog on Ice: \& Other Curious Expressions.1. Izdaja 1948. New York: William Morrow Paperbacks.

Jakop, Nataša. 2005. Pragmatična frazeologija. Ljubljana: Založba ZRC.

Keber, Janez. 1998. Živali v prispodobah 2. Celje: Mohorjeva družba.

Kingsley, Charles. 1995. Povodni otroci. Ljubljana: Karantanija.

Krüger-Lorenzen, Kurt. 1995. Deutsche Redensarten und was dahinter steckt. München: Wilhelm Heyne Verlag.

Kržišnik, Erika. 2006. Izraba semantične potence frazemov. V: Slovensko jezikoslovje danes. Slavistična revija. Posebna številka. Vidovič Muha, Ada (red.). Ljubljana: Slavistično društvo Slovenije. 259-279.

Kržišnik, Erika. 2008. Viri za kulturološko interpretacijo frazeoloških enot. Jezik in slovstvo. 53/1: 33-47.

Malenšek, Mimi. 1970. Pojoči labodi. Ljubljana: DZS.

Marinčič, Katarina. 1992. Rožni vrt. Celovec - Salzburg: Wieser.

Piirainen, Elisabeth. 2012. Widespread Idioms in Europe and Beyond. Toward a Lexicon of Common Figurative Units. New York: Peter Lang.

Svetina, Tone. 1965. Ukana. Ljubljana: Borec.

Taylor, Archer. 1954. Proverbial Comparisons and Similes from California. Berkeley: University of California Press.

Thackeray, William Makepeace. 1946. Semenj ničevosti: roman brez junaka. Ljubljana: DZS.

Toporišič, Jože. 1973-1974. K izrazju in tipologiji slovenske frazeologije. Jezik in slovstvo. 19/8: 273-279.

Trokhimenko, Olga V. 1999. Wie ein Elefant im Porzellanladen: Ursprung, Überlieferung und Gebrauch der Redensart im Deutschen und im Englischen. Proverbium. 16: 351-380.

Zorn, Aleksander. 1999. Nacionalni junaki, narcisi in stvaritelji. Ljubljana: Mladinska knjiga.

\section{SLOVARJI}

Dornseiff, Franz. 1970. Der deutsche Wortschatz nach Sachgruppen. [izd. 7]. Berlin - New York: Walter de Gruyter.

Duden 11. Redewendungen und sprichwörtliche Redensarten. 1992. Drosdowski, Günther; Scholze-Stubenrecht, Werner (red.). [izd. 1]. Mannheim: Bibliographisches Institut. 
Duden 11. Redewendungen: Wörterbuch der deutschen Idiomatik. 2008. Dudenredaktion (red.). [izd. 3]. Mannheim: Bibliographisches Institut.

Engeroff, Karl; Lovelace-Käufer, Cicely. 1983. An English-German Dictionary of Idioms. [izd. 5]. München: Max Hueber Verlag.

Jenko, Elizabeta M. 1994. Deutsch-slowenisches Wörterbuch der Redewendungen mit einer kontrastiven Studie. Klagenfurt - Celovec: Drava.

Keber, Janez. 2011. Slovar slovenskih frazemov. Ljubljana: Založba ZRC.

Messinger, Heinz; Rüdenberg, Werner. 1986. Langenscheidts Handwörterbuch. Englisch-Deutsch, Deutsch-Englisch. [izd. 17]. Berlin - München: Langenscheidt.

Slovar slovenskega knjižnega jezika. I-IV. 1970-1991. Ljubljana: DZS.

Snoj, Marko. 1997. Slovenski etimološki slovar. Ljubljana: Založba Mladinska knjiga.

Slovar slovenskega knjižnega jezika. I-IV. 1970-1991. Ljubljana: DZS.

\section{SPLETNI VIRI}

Arbuthnot, John. 1712. Law is a bottomless-Pit. Or, The History of John Bull.

https://archive.org/stream/historyofjohnbul02643gut/jhnbl10.txt

Besedilni korpus Nova beseda

http://bos.zrc-sazu.si/s_beseda3.html

Besedilni korpus Gigafida

http://www.gigafida.net/

Burckhardt, John Lewis. 1830. Arabic proverbs, or the manners and customs of the modern Egyptians.

http://www.archive.org/details/arabicproverbso00burcgoog

Burckhardt, Johann Ludwig. 1834. Arabische Sprüchwörter oder die Sitten und Gebräuche der neueren Aegpytier.

http://www.archive.org/details/arabischesprchw00kirmgoog

Garfield 2.

http://www.kolosej.si/filmi/film/garfield_2_s_podnapisi

Johnson, Samuel. 1768. A Dictionary of the English Language.

http://www.archive.org/details/adictionaryengl03unkngoog

Kingsley, Charles. 1916. The Water-Babies.

http://hdl.handle.net/2027/nc01.ark:/13960/t1kh1nv99

Knowlton, Brian. 2005. Bush Nominee for U.N. Envoy Is Pressed Hard at Senate Hearing. http://www.nytimes.com/2005/04/11/international/middleeast/11 cnd-bolt.html?pagewante$\mathrm{d}=$ print\&position $=\& \_\mathrm{r}=0$

Ločniškar-Fidler, Mateja. 2003. Elektronska knjiga - knjiga brez papirja. Knjižnica. 47, 1/2: 147-174.

http://www.dlib.si/?URN=URN:NBN:SI:DOC-5CIUMQ0F Datum vpogleda: 20. 4. 2014. 
Lucas, Newton Ivory. 1854. Englisch-deutsches und deutsch-englisches Wörterbuch; mit besonderer Rücksicht auf den gegenwärtigen Standpunkt der Literatur und Wissenschaft. http://www.archive.org/details/pt01englischdeutsche01lucauoft

Marryat, Frederick. 1834. Jacob Faithful

http://www.gutenberg.org/ebooks/21549

Marryat, Frederick. 1835. Jacob Ehrlich: ein Seitenstück zu Peter Simpel, vom nemlichen Verfaßer.

http://www.mdz-nbn-resolving.de/urn/resolver.pl?urn=urn:nbn:de:bvb: 12-bsb11091211-2 Datum vpogleda: 12. 2. 2014.

Marryat, Frederick. 1843. Jacob Ehrlich.

http://www.mdz-nbn-resolving.de/urn/resolver.pl?urn=urn:nbn:de:bvb:12-bsb10747587-2 Datum vpogleda: 12. 2. 2014.

Marryat, Frederick. 1860. Jacob Ehrlich.

http://gutenberg.spiegel.de/buch/3828/1 Datum vpogleda: 12. 2. 2014.

Moore, Thomas. 1817. Lalla Rookh.

http://www.archive.org/details/lallarookh00unkngoog

Moore, Thomas. 1826-1843. Lalla Rookh.

https://download.digitale-sammlungen.de/pdf/1398375779bsb10747816.pdf

Murko, Anton. 1833. Deutsch-Slowenisches und Slowenisch-Deutsches Handwörterbuch. http://www.dlib.si/?URN=URN:NBN:SI:DOC-T28EEL0U

Muršec-Živkov, Jožef. 1866. Narava in človek. Slon.

http://www.dlib.si/?URN=URN:NBN:SI:DOC-7XOTL99T Datum vpogleda: 12. 2. 2014

Preview: Garfield: A Tail of Two Kitties

http:/www.ign.com/articles/2006/06/12/preview-garfield-a-tail-of-two-kitties

Ostro zaslišanje kandidata za veleposlanika ZDA pri OZN Johna Boltona

http://www.dnevnik.si/svet/120991

Thackeray, William Makepeace. 1848. Vanity Fair. Volume II.

http://www.mdz-nbn-resolving.de/urn/resolver.pl?urn=urn:nbn:de:bvb:12-bsb10750522-4

Thackeray, William Makepeace. 1849. Der Markt des Lebens. Ein Roman ohne einen Helden. August Diezmann (prev.).

http:/www.mdz-nbn-resolving.de/urn/resolver.pl?urn=urn:nbn:de:bvb:12-bsb10751856-1

Thackeray, William Makepeace. 1851. Jahrmarkt der Eitelkeit. Christoph Friedrich Grieb (prev.). http://gutenberg.spiegel.de/buch/2801/33 Datum vpogleda: 16. 2. 2014.

Thackeray, William Makepeace. 1851. Jahrmarkt der Eitelkeit. Christoph Friedrich Grieb (prev.). Stuttgart: Franckh

http:/www.mdz-nbn-resolving.de/urn/resolver.pl?urn=urn:nbn:de:bvb:12-bsb10750591-1

Thackeray, William Makepeace. 1964. Jahrmarkt der Eitelkeit. 2 Bände, Berlin 1964, Band 1. Christoph Friedrich Grieb (prev.).

http://www.zeno.org/nid/20005777402 
The Quaterly Review. Vol. 125. 1868.

http://www.archive.org/details/britishquaterly00stougoog

The Spectator. 1861.

http://archive.spectator.co.uk/article/26th-october-1861/17/some-village-papers

Trošt, Ivo. 1911. Zvonček (Ljubljana).

http://www.dlib.si/?URN=URN:NBN:SI:DOC- AW5O1V2L Datum vpogleda: 12. 2. 2014.

Vetter-Liebenow, Gisela. 2012. Karikatur und Zeichenkunst. Verzeichnis. Hannover: Wilhelm-

Busch-Gesellschaft.

http://mail.farbecht.de/ftp/Passavia/239-288\%20Verzeichnis\%20Karikatur\%20fe.indd.pdf

\section{ZUSAMMENFASSUNG}

\section{Wer befindet sich im Porzellanladen? - Analyse von Tierkomponenten im Phrasem unter diachronem Aspekt}

Der diachrone Aspekt in der Phraseologieforschung ist Gegenstand zahlreicher Untersuchungen, in denen Linguisten den Gebrauch und die Gesetzmäßigkeiten in der Entwicklung einer festen Wortverbindung vom Anfang bis zu unserer Zeit feststellen. Bei der Erforschung der Etymologie eines Phrasems müssen verschiedene Möglichkeiten seiner Entstehung und alle Faktoren berücksichtigt werden, die die Bildung einer neuen Wortverbindung möglicherweise beeinflussen. Es gibt verschiedene Arten der Bildung von phraseologischen Einheiten: entweder wird aus der ursprünglichen freien Wortverbindung eine feste Wortverbindung infolge der metaphorischen oder metonymischen Bedeutungsübertragungen gebildet, oder wenn einzelne Komponenten ihre ursprüngliche Bedeutung verlieren und die neue phraseologische Bedeutung annehmen, oder wenn die ursprüngliche Motivation im Prozess der volksetymologischer Umwandlung zur Entstehung demotivierter Phraseme führt, oder auch als Entlehnung aus anderen Sprachen. In unserem Beitrag stellen wir die Etymologie des Phrasems slon v trgovini $s$ porcelanom fest, das in germanischen, romanischen, slawischen und anderen Sprachen auch mit anderen Tierkomponenten (z.B. Pferd, Stier, Kuh, Kamel) bekannt ist. Der exakte Ursprung des Phrasems ist nicht bekannt. Auf der Grundlage des kontrastiven Vergleichs klären wir mehrere mögliche Theorien der Entstehung. Die Analyse des Untersuchungsmaterials aus historischen und modernen literarischen und anderen Belegen sowie Wörterbüchern erfolgt sowohl auf der strukturellen und semantischen Ebene als auch unter dem übersetzungsbezogenen Aspekt.

Schlüsselwörter: Etymologie, Tierkomponente, Übersetzung, Konnotation, Lexikographie 